\title{
Bone recurrence after radical hysterectomy and lymphadenectomy in early-stage cervical cancer
}

\section{Erken dönem servikal kanserde radikal histerektomi ve lenfadenektomi sonrası kemik nüksü}

\author{
(D) Caner Çakır, (1) Dilek Yüksel, (1) Çiğglem Kılıç, (1) Mehmet Ünsal, (1) Rıza Dur, (1) Gökhan Boyraz, \\ (D) Alper Karalok, (1) Özlem Moraloğlu Tekin, (1) Taner Turan
}

Etlik Zübeyde Hanım Women's Health Training and Research Hospital, Clinic of Gynecologic Oncology, Ankara, Turkey

\begin{abstract}
Objective: To present the clinical, surgical, and pathologic features of bone recurrence in patients who underwent radical hysterectomy for early-stage uterine cervical cancer.

Materials and Methods: Data of 412 patients who underwent type III radical hysterectomy and pelvic \pm paraaortic lymphadenectomy for stage 1B-2A epithelial cervical cancer were reviewed. Seven (1.7\%) patients with bone recurrence in the first recurrence were included in the study.

Results: The median follow-up of the main cohort $(\mathrm{n}=412)$ was 46 (range=1-300) months. In this period, recurrence developed in 53 (12.9\%) patients and recurrence was observed in bone in 13.2\% (7 of 53) of these recurrences. Time to recurrence ranged from 9 to 45 months. Of the recurrences, five were in the axial skeleton and two were in the appendicular skeleton. Recurrence was observed in lumbar vertebrae in three patients, thoracic vertebrae in one patient, sacral vertebrae in one patient, lumbosacral vertebrae in one patient, and the left femur in two patients. Four patients had multiple recurrence in 3 patients despite isolated bone recurrence. Patients with multiple recurrences died within 6-25 months. All isolated bone recurrences were in the axial skeleton. Complete clinical response with salvage therapy was achieved in two patients with isolated bone recurrence.

Conclusion: Complete clinical response and long postoperative survival can be achieved with salvage treatment when bone recurrence is solitary in cervical cancers. Keywords: Bone recurrence, uterine cervical cancer, survival, salvage therapy

$\ddot{O} z$

Amaç: Erken evre uterin servikal kanser için radikal histerektomi yapılan hastalarda kemik nüksünün klinik, cerrahi ve patolojik özelliklerini sunmayı amaçladık. Gereç ve Yöntemler: Evre 1B-2A epitelyal servikal kanser için tip 3 radikal histerektomi ve pelvik \pm paraaortik lenfadenektomi uygulanan 412 hastanın verileri gözden geçirildi. Çalışmaya ilk nüksde kemik nüksü olan 7 hasta $(\% 1,7)$ dahil edildi.

Bulgular: Ana kohortun ortanca takip süresi (n=412) 46 aydı (1-300 ay). Bu dönemde, 53 hastada (\%12,9) nüks gelişti ve bu nükslerin \%13,2'sinde (53) 7'sinde kemikte nüks gözlendi. Nüks zamanı 9 ila 45 ay arasında değişmekteydi. Nükslerin 5'i aksiyal iskelet, 2'si apendiküler iskeletteydı. Üç hastada lomber vertebra, 1 hastada torasik vertebra, 1 hastada sakral vertebra, 1 hastada lumbosakral omur ve 2 hastada sol femur saptandı. Dört hastada izole kemik nüksüne rağmen 3 hastada çoklu nüks vardı. Çoklu nüks olan hastalar 6-25 ay içerisinde öldüler. İzole kemik nükslerinin tümü aksiyal iskelette idi. İzole kemik nüksü olan 2 hastada kurtarma tedavisi ile tam klinik yanıt sağlandı.
\end{abstract}

Sonuç: Servikal kanserlerde kemik nüksü tek olduğunda, salvage tedavisi ile tam klinik yanıt ve postoperatif uzun sağkalım sağlanabilir.

Anahtar Kelimeler: Kemik nüksü, rahim rahim ağzı kanseri, sağkalım, kurtarma tedavisi

\section{Introduction}

Uterine cervical cancer (CC) is the third most common cause of cancer having the highest mortality rate in the female reproductive system ${ }^{(1)}$. Prognostic factors of CC are based on stage, patient age, type and size of tumor, lymph node metastases, parametrial invasion, and lymphovascular space invasion $^{(2,3)}$. Mostly, recurrence occurs within 2 years after primary treatment and $90 \%$ of patients with recurrence die $^{(4,5)}$. The 10-year recurrence rate is reported as 3\% for stage IA, 16\%

PRECIS: To identify the possible risk factors for postpartum urinary retention.

Address for Correspondence/Yazışma Adresi: Caner Çakır, MD,

Etlik Zübeyde Hanım Women's Health Training and Research Hospital, Clinic of Gynecologic Oncology, Ankara, Turkey

E-mail: caner4084@gmail.com ORCID ID: orcid.org/0000-0003-2559-9104

Received/Gelis Tarihi: 19.04.2019 Accepted/Kabul Tarihi: 12.10.2019

${ }^{\oplus}$ Copyright 2019 by Turkish Society of Obstetrics and Gynecology

Turkish Journal of Obstetrics and Gynecology published by Galenos Publishing House. 
for stage IB, 31\% for stage IIA, 26\% for stage IIB, 39\% for stage III, and $75 \%$ for stage IVA ${ }^{(6)}$.

Just like other solid tumors, CC spreads through direct invasion, and lymphatic and hematogenous dissemination. Distant metastasis to other organs such as lung, bone, braini and liver uses the hematogenous route primarily ${ }^{(7,8)}$. Distant organ metastasis is most commonly seen in lungs (21\%), bone (16\%), para aortic nodes (11\%), the intestinal space (8\%), and supraclavicular lymph nodes (7\%). The number and site of metastasis are important for survival. The median survival is 24 weeks in lymphatic recurrence, whereas it is only 12 weeks in metastasis to other organs ${ }^{(6)}$. Patients with stage I-IIA CC who undergo surgery have bone recurrence in the first 2 years of the postoperative period, and usually the recurrence occurs in axial bone, especially in the vertebra ${ }^{(9,10)}$. The median survival after bone recurrence is reported as between 5 and 12 months $^{(9-12)}$. In this research, our aim was to evaluate the clinical, surgical, and pathologic factors in patients with bone recurrence after type III radical hysterectomy with pelvic \pm para aortic lymphadenectomy for CC.

\section{Materials and Methods}

Between 1993 and 2018, 412 patients with stage IB-IIA epithelial $\mathrm{CC}$ as classified by the International Federation of Obstetricians and Gynecologists (2014) were treated with laparotomy and type III radical hysterectomy with pelvic \pm paraaortic lymphadenectomy, and their data were reviewed. Seven (1.7\%) patients who had the first recurrence in bone were included. Data of the patients' clinical findings, site of recurrence, time to recurrence, treatment modality, and the response rates were obtained from the patient files and pathology reports in our gynecologic oncology clinic electronic database system.

Bone scintigraphy, magnetic resonance imaging, and positron emission tomography-computed tomography (PET-CT) were used in the diagnosis of metastatic lesions. For the differential diagnosis of metastasis, systemic examination, chest X-ray, abdominopelvic and thoracic CT and PET-CT were performed. Recurrence that developed only in bone was classified as "isolated recurrence" and bone and other sites were classified as "multiple recurrences". Recurrence of the bone was classified as "axial skeleton", which included cranium, sternum, vertebra and costa, and "appendicular skeleton", which included the upper and lower extremities, scapula, and the pelvic bones. The size of the tumor was defined by the largest diameter of the tumor in the cervix at the initial treatment.

The plan of treatment in the patients with recurrence was decided by the council of gynecology and oncology. Treatment results were evaluated according to the guidelines of the World Health Organization. We defined the clinical response as follows: (I) complete clinical response: disappearance of the macroscopic tumor; (II) partial clinical response: shrinkage over $50 \%$ of the macroscopic tumor, (III) stable disease: macroscopic shrinkage of the tumor less than $50 \%$ or not less than $25 \%$ growth; (IV) progressive disease: more than $25 \%$ growth of the macroscopic tumor or macroscopic appearance of new tumor foci ${ }^{(13)}$.

The factors indicating the bone recurrence could not be recognized at this point, because the number of the patients with bone recurrence were only $7(1.7 \%)$. The time of from surgery until recurrence was defined as time-to-recurrence (TTR), the time until the death of the patient was defined as overall survival, and the time of recurrence until the death of patient or until the last date was defined as post recurrence survival.

All patients were followed up after the initial treatment for the CC. Patients who had complete clinical response with salvage treatment for recurrence were followed up quarterly in the first 2 years, semi-annually for up to 5 years, and annually thereafter. Pelvic examination, abdominopelvic ultrasonography, Papanicolaou smear, complete blood count, and biochemistry profile were performed in the follow-up. Chest X-ray was used annually unless there was clinical suspicion. Thoracic andlor abdominal CT were used when needed.

\section{Results}

The median follow-up of the main cohort $(n=412)$ was 46 (range=1-300) months. In this period, recurrence developed in $53(12.9 \%)$ patients, and the recurrence rate in bone was observed as $13.2 \%$ (7 of 53). Tumor type was squamous carcinoma in six patients and mixed type in one patient (squamous + adenocarcinoma). Paraaortic lymphadenectomy was added to the surgical procedures in six patients and pelvic lymphadenectomy alone was performed in one patient. The number of lymph nodes removed was between 42 and 102 . It was determined that there was spread to the pelvic lymph nodes in two patients and pelvic and paraaortic lymph nodes in one patient. There was parametrial invasion in one patient, surgical border positivity in one, and lymphovascular space invasion in two patients. The surgical-pathologic features are shown in Table 1.

One patient (patient \#7) received neo-adjuvant chemotherapy. As neoadjuvant chemotherapy, the patient received a combination of cisplatin + tegafur-uracil for 2 cycles. Adjuvant therapy was given to three patients as concurrent chemoradiotherapy (CCRT) and three patients received no adjuvant therapy. One patient (patient \#4) refused adjuvant therapy.

TTR ranged from 9 to 45 months. Five of the recurrences were in the axial skeleton and two were in the appendicular skeleton. Recurrence was observed in three patients in the lumbar vertebrae, one in the thoracic vertebrae, one in the sacral vertebrae, one in the lumbosacral vertebrae, and two in the left femur. Three patients (patient \#1, \#6, and \#7) had isolated bone recurrence and four patients had multiple recurrence. Except for the bone, one of them had it in the inguinal and supraclavicular lymph nodes, one in pelvic-paraaortic lymph nodes, one in lung and paraaortic lymph nodes and one in lung 
(Table 2). Recurrence was in the axial skeleton in all isolated bone recurrences.

After recurrence, six patients received salvage therapy for curative intent and one patient received palliative therapy (patient \#4). Two of the patients who received salvage therapy were given only systemic treatment (cisplatin +5 fluorouracil). Four patients received radiotherapy, two of whom were given systemic treatment after radiotherapy. Radiotherapy was performed in one patient with weekly cisplatin (CCRT) and one patient received radiotherapy only (Table 2 ). In salvage therapy, one patient with only systemic treatment and one patient with radiotherapy had a complete clinical response (patients \#1 and \#7). These two patients had isolated bone recurrence and their post recurrence survival was 129 months and 11 months, respectively. During the follow-up period, four patients died because of the disease (patient \#2, \#3, \#4 and \#5). The recurrence type of these four patients was multiple recurrence, and in two the disease recurred in the lung (Table 2). These patients died within 6-25 months after recurrence. Recurrence was seen in the femur and pelvic paraaortic lymph nodes of the patient who lived up to 25 months after recurrence and was treated with concurrent chemo-radiotherapy.

\section{Discussion}

The results of bone recurrence in uterine CC vary widely. Drescher ${ }^{(14)}$ reported bone metastasis in $1.2 \%$. However, this rate was $16 \%$ in the study of Fagundes et al. ${ }^{(6)}$. In our case

Table 1. Clinical, pathologic, and surgical features

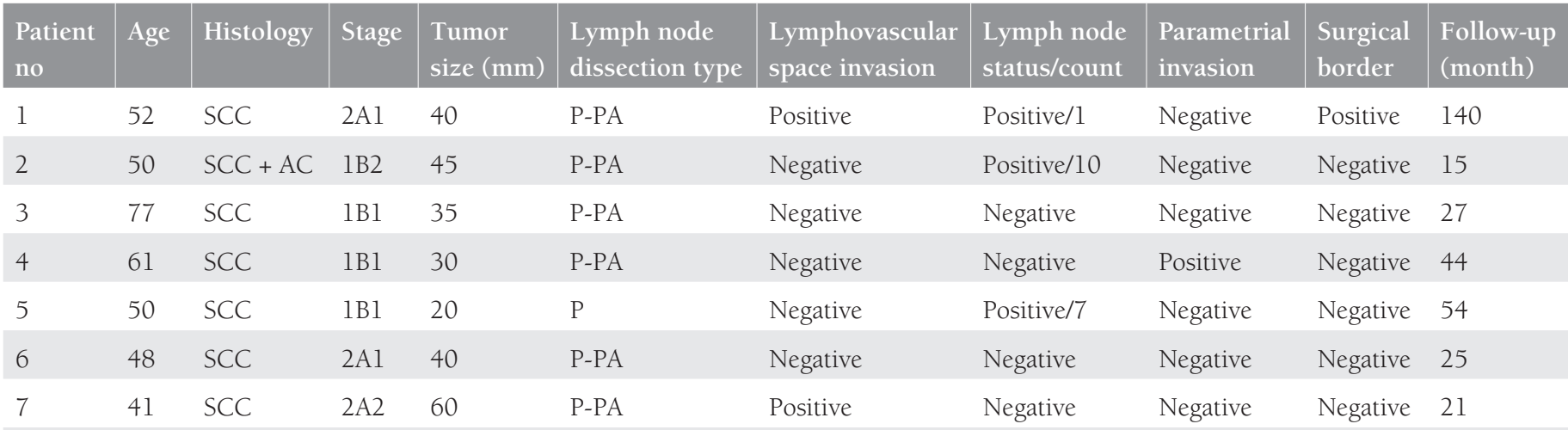

P-PA: Pelvic-paraaortic, P: Pelvic, AC: Adenocarcinoma, SCC: Squamous cell carcinoma, tumor size is the initial size

Table 2. Bone metastasis site, treatment and outcome

\begin{tabular}{|c|c|c|c|c|c|c|c|c|c|}
\hline $\begin{array}{l}\text { Patient } \\
\text { no }\end{array}$ & $\begin{array}{l}\text { Adjuvant } \\
\text { therapy }\end{array}$ & $\begin{array}{l}\text { TTR } \\
\text { (month) }\end{array}$ & $\begin{array}{l}\text { Recurrent } \\
\text { bone site }\end{array}$ & Bone type & $\begin{array}{l}\text { Other } \\
\text { recurrence site }\end{array}$ & $\begin{array}{l}\text { Salvage } \\
\text { therapy for } \\
\text { recurrence }\end{array}$ & $\begin{array}{l}\text { Outcome } \\
\text { of salvage } \\
\text { therapy }\end{array}$ & $\begin{array}{l}\text { Died of } \\
\text { disease }\end{array}$ & $\begin{array}{l}\text { Postrecurrence } \\
\text { survival } \\
\text { (month) }\end{array}$ \\
\hline 2 & CCRT & 9 & Femur (left) & $\begin{array}{l}\text { Appendicular } \\
\text { skeleton }\end{array}$ & $\begin{array}{l}\text { Inguinal LN + } \\
\text { Supraclavicular } \\
\text { LN }\end{array}$ & Cisplatin + 5FU & Progression & Positive & 6 \\
\hline 3 & None & 9 & Femur (left) & $\begin{array}{l}\text { Appendicular } \\
\text { skeleton }\end{array}$ & $\begin{array}{l}\text { Pelvic- } \\
\text { paraaortic LN }\end{array}$ & CCRT & Progression & Positive & 25 \\
\hline 4 & Nonel & 38 & $\begin{array}{l}\text { Thoracic } \\
\text { vertebra }\end{array}$ & $\begin{array}{l}\text { Axial } \\
\text { skeleton }\end{array}$ & $\begin{array}{l}\text { Lung + } \\
\text { Paraaortic LN }\end{array}$ & Palliative & Progression & Positive & 6 \\
\hline 7 & None & 10 & $\begin{array}{l}\text { Lumbosacral } \\
\text { vertebra }\end{array}$ & $\begin{array}{l}\text { Axial } \\
\text { skeleton }\end{array}$ & None & RT & $\begin{array}{l}\text { Complete } \\
\text { clinical } \\
\text { response }\end{array}$ & Negative & 11 \\
\hline
\end{tabular}

TTR: Time-to-recurrence, CCRT: Concurrent chemoradiotherapy, RT: Radiotherapy, CT: Chemotherapy, 5FU: 5-fluorouracil, LN: Lymph node,

${ }^{1}$ Patient refused treatment 
series, the rate of bone recurrence was $1.3 \%$ in the main cohort where the median follow-up was 46 months.

The site and number of recurrences are the main factors affecting prognosis and treatment ${ }^{(15)}$. It is known that the success of treatment is low when recurrence occurs in others site accompanying the bone recurrence ${ }^{(16)}$. In the current case series, all patients with multiple recurrences died of recurrent disease. The choice of treatment for recurrent disease is primarily dependent on previous treatment and should be evaluated together with the location of the recurrent tumor and the patient's performance ${ }^{(17,18)}$. In patients with CC who have distant and multiple recurrent disease, the primary aim of treatment is mostly not-curative intent but palliative ${ }^{(19)}$. However, in a study presented by Makino et al. ${ }^{(20)}$ of 75 patients with uterine CC and bone recurrence, the overall survival (OS) of 16 patients who received chemotherapy and CCRT after RT was 18 months and 2 months, respectively, compared with 25 patients receiving palliative treatment $(p<0.05)$. In our case series, complete clinical response was obtained with salvage treatment in two patients in the presence of isolated recurrence. Salvage treatment was applied to one of them with systemic treatment, and with cisplatin and radiotherapy to the other. In recurrent CC, cisplatin is preferred for most patients. Systemic treatment success rate is $12-22 \%$ in recurrent $C^{(21-26)}$. Unlike other anti-angiogenic agents, bevacizumab has been used as a part of cisplatin-based combination therapy for recurrent, persistent or metastatic CC, and its addition to the cisplatinpaclitaxel protocol has been shown to increase OS from 13 months to 17 months $(\mathrm{p}=0.008)^{(27,28)}$. Surgical treatment has been applied in selected cases with solitary bone recurrence in the literature. Ida et al. ${ }^{(29)}$ were able to control the disease by surgical resection in a solitary femur recurrence that developed 22 months after the first treatment. However, Makino et al. ${ }^{(20)}$ reported that in two patients with solitary bone recurrence, complete resection could not be achieved. We had no patients who could be managed surgically in this series.

The retrospective nature is the main limitation of the study. The number of patients was low and this prevented clear results to change clinical practice. However, the study evaluated patients who had a median follow-up of approximately 4 years and who had undergone radical surgery from among more than 400 early-stage cancers.

\section{Conclusion}

In conclusion, complete clinical response and long postoperative survival can be achieved with salvage treatment when bone recurrence is solitary. However, the effect of surgery in this patient group should be evaluated. Multimodal treatment options including surgery in CC with bone recurrence, especially solitary recurrence, need to be evaluated in further studies.

\section{Ethics}

Ethics Committee Approval: Local ethics committee approval was obtained.

Informed Consent: Approval from all patients.

Peer-review: External and internal peer-reviewed.

\section{Authorship Contributions}

Surgical and Medical Practices: C.Ç., T.T., Concept: C.Ç., R.D., D.Y., Ç.K., Design: C.Ç., Data Collection or Processing: C.Ç., M.Ü., Analysis or Interpretation: C.Ç., Literature Search: C.Ç., G.B., A.K., Ö.M.T., T.T., Writing: C.Ç.

Conflict of Interest: No conflict of interest was declared by the authors.

Financial Disclosure: The authors declared that this study received no financial support.

\section{References}

1. Siegel R, Ma J, Zou Z, Jemal A. Cancer statistics, 2014. CA Cancer J Clin 2014;64:9-29

2. Quinn MA, Benedet JL, Odicino F, Maisonneuve P, Beller U, Creasman WT, et al. Carcinoma of the cervix uteri. FIGO 26th Annual Report on the Results of Treatment in Gynecological Cancer. Int J Gynaecol Obstet 2006;95:S43-103.

3. Kimyon Comert G, Turkmen O, Karalok A, Basaran D, Bulbul D, Turan $\mathrm{T}$. Therapy modalities, prognostic factors, and outcome of the primary cervical carcinosarcoma: meta-analysis of extremely rare tumor of cervix. Int J Gynecol Cancer 2017;27:1957-69.

4. Webb MJ, Symmonds RE. Site of recurrence of cervical cancer after radical hysterectomy. Am J Obstet Gynecol 1980;138:813-7.

5. Peiretti M, Zapardiel I, Zanagnolo V, Landoni F, Morrow CP, Maggioni A. Management of recurrent cervical cancer: a review of the literature. Surg Oncol 2012;21:59-66.

6. Fagundes H, Perez CA, Grigsby PW, Lockett MA. Distant metastases after irradiation alone in carcinoma of the uterine cervix. Int J Radiat Oncol Biol Phys 1992;24:197-204.

7. Carlson V, Delclos L, Fletcher GH. Distant metastases in squamouscell carcinoma of the uterine cervix. Radiology 1967;88:961-6.

8. Carvalho L, Azevedo I, Salgado L, Ferreira ES, Henrique R, de Carvalho RG, et al. Squamous cell carcinoma of the cervix metastatic to the spleen - case report. Gynecol Oncol 1997;67:107-10.

9. Thanapprapasr D, Nartthanarung A, Likittanasombut P, Na Ayudhya NI, Charakorn C, Udomsubpayakul U, et al. Bone metastasis in cervical cancer patients over a 10-year period. Int J Gynecol Cancer 2010;20:373-8.

10. Yoon A, Choi CH, Kim HJ, Park JY, Lee YY, Kim TJ, et al. Contributing factors for bone metastasis in uterine cervical cancer. Int J Gynecol Cancer 2013;23:1311-7.

11. Kanayama T, Mabuchi S, Shimura K, Hisamatsu T, Isohashi F, Hamasaki T, et al. Prognostic factors for survival in cervical cancer patients with bone metastasis. Eur J Gynaecol Oncol 2015;36:2903.

12. Matsumiya H, Todo Y, Okamoto K, Takeshita S, Yamazaki H, Yamashiro K, et al. A prediction model of survival for patients with bone metastasis from uterine cervical cancer. J Gynecol Oncol 2016;27:e55.

13. WHO handbook for reporting results of cancer treatment. WHO Offset Publication. 1979;No:48 
14. Drescher H. To the clinic of adenocarcinoma of the cervix uteri. Ceburtshilfe Frauenheilkd 1949;9:31-7.

15. Moore DH, Tian C, Monk BJ, Uzun HJ, Omura GA, Parlak JD. Prognostic factors for response to cisplatin-based chemotherapy in advanced cervical carcinoma: A gynecologic oncology group study. Gynecol Oncol 2010;116:44-9.

16. Monk BJ Tewari KS. Evidence-based therapy for recurrent cervical cancer. J Clin Oncol 2014;32:2687-90.

17. Koh WJ, Greer BE, Abu-Rustum NR, Apte SM, Campos SM, Cho KR, et al. Cervical Cancer, Version 2.2015. J Natl Compr Canc Netw 2015;13:395-404.

18. Mabuchi S, Isohashi F, Yoshioka Y, Temma K, Takeda T, Yamamoto $\mathrm{T}$, et al. Prognostic factors for survival in patients with recurrent cervical cancer previously treated with radiotherapy. Int J Gynecol Cancer 2010;20:834-40.

19. Matsuyama T, Tsukamoto N, Imachi M, Nakano H. Bone metastasis from cervix cancer. Gynecol Oncol 1989;32:72-5.

20. Makino H, Nishio S, Tsubamoto H, Shimada M, Nishikawa R, Kai $\mathrm{K}$, et al. Treatment and prognosis of bone metastasis from cervical cancer (KCOG-G1202s). J Obstet Gynaecol Res 2016;42:701-6.

21. Rose PG, Blessing JA, Gershenson DM, McGehee R. Paclitaxel and cisplatin as first-line therapy in recurrent or advanced squamous cell carcinoma of the cervix: a gynecologic oncology group study. J Clin Oncol 1999;17:2676-80.

22. Pignata S, Silvestro G, Ferrari E, Selvaggi L, Perrone F, Maffeo A, et al. Phase II study of cisplatin and vinorelbine as first-line chemotherapy in patients with carcinoma of the uterine cervix. J Clin Oncol 1999;17:756-60.
23. Kurtz JE, Freyer G, Joly F, Gladieff L, Kaminski MC, Fabbro M, et al; GINECO Group, France. Combined oral topotecan plus carboplatin in relapsed or advanced cervical cancer: a GINECO phase I-II trial. Anticancer Res 2012;32:1045-9.

24. Bonomi P, Blessing JA, Stehman FB, DiSaia PJ, Walton L, Major FJ. Randomized trial of three cisplatin dose schedules in squamous cell carcinoma of the cervix: a Gynecologic Oncology Group Study. J Clin Oncol 1985;3:1079-85.

25. Lahousen M, Haas J, Pickel H, Hackl A, Kurz C, Ogris H, et al. Chemotherapy versus radiotherapy versus observation for high risk cervical carcinoma after radical hysterectomy: a randomized prospective, multicenter trial. Gynecol Oncol 1999;73:196-201.

26. Tambaro R, Scambia G, Di Maio M, Pisano C, Barletta E, Iaffaioli VR, et al. The role of chemotherapy in locally advanced, metastatic and recurrent cervical cancer. Crit Rev Oncol Hematol 2004;52:3344.

27. Mackay HJ, Tinker A, Winquist E, Thomas G, Swenerton K, Oza A, et al. A phase II study of sunitinib in patients with locally advanced or metastatic cervical carcinoma: NCIC CTG Trial IND.184. Gynecol Oncol 2010;116:163-7.

28. Tewari KS, Sill MW, Long HJ III, Penson RT, Huang H, Ramondetta LM, et al. Improved survival with bevacizumab in advanced cervical cancer. N Engl J Med 2014;370:734-43.

29. Ida T, Goto T, Motoi T, Nagai I, Matsubara S, Fujiwara H, et al. Surgical removal of an isolated femoral metastasis of uterine cervical squamous cell carcinoma: a case report and review of the literature. Eur J Gynaecol Oncol 2017;38:122-5. 